\title{
Reproductive cycle of the endemic and threatened fish Puntius shalynius (Cypriniformes: Cyprinidae) in Meghalaya, India
}

\author{
Maisnam Manorama \& Sunkam Narayanalyengar Ramanujam \\ Fish Biology Laboratory, Department of Zoology, School of Life Sciences, North Eastern Hill University, Shillong - \\ 793022, India; maisnamanorama@gmail.com, ramanujamsunkam@gmail.com
}

\author{
Received 01-III-2016. C Corrected 07-VIII-2016. $\quad$ Accepted 07-IX-2016.
}

\begin{abstract}
Puntius shalynius is a highly endemic freshwater minor carp that is economically important and is threatened because of its ornamental value. The present investigation evaluated this barb gonadal maturation, based on morphology and spawning of this species in the Umiam river, Meghalaya, India. The population of this indigenous fish has declined due to its fragmented distribution and exploitation as an ornamental fish. The reproductive cycle of $P$. shalynius was studied for the first time. A total of 609 fish samples were randomly collected from the river for a period of two years during January 2010 and December 2011. Five maturity phases (rest, primary growth, secondary growth, ripe and spent) were observed on the basis of ovarian and testicular macroscopic evaluation throughout the annual cycle. Peak spawning activity was observed in the month of June/ July and it coincided with the start of the monsoon season. The study showed that the fish spawns once in a year with single spawning peak and that the species is a low fecund fish. It is important to conserve this species for its unique ecological value and urgent management policies should promote its sustainable utilization. Rev. Biol. Trop. 65 (1): 255-265. Epub 2017 March 01.
\end{abstract}

Key words: Puntius shalynius, endemic, ornamental, gonadosomatic index, India.

The shalyni barb, Puntius shalynius (Yazdani \& Talukdar, 1975), is an important hill stream, endemic and threatened ornamental fish of Meghalaya, India. This species has a very restricted geographical distribution in India (Manorama \& Ramanujam, 2014) and inhabits high altitude water bodies above 1 $000 \mathrm{msl}$. It is an omnivorous fish, with 5.60 $\mathrm{cm}$ of average length (Manorama \& Ramanujam, 2011). The phenotypic appearance of $P$. shalynius is characterized by having short, compressed, fairly deep body and dorsal profile a little more convex than the ventral profile. In some males, minute white tubercles are present on the head. Barbels are absent and scales are fairly big, hexagonal with anterior margins distinctly wavy. Two spots on either sides of the tail in both sexes, the anterior one (situated nearly opposite the end of the anal) more distinct than the posterior (situated near the base of the caudal). There is a blue horizontal line which runs along the middle of body and presence of minute black spots on sides of head (Jayaram, 1999). It has been in the category of "vulnerable" according to IUCN (2015), and has considered it in threatened status.

The vulnerable aspects of life histories of threatened freshwater fishes are very important to be identified in order to add to their conservation measures (Angermeier, 1995). Furthermore, the knowledge of their reproductive biology is a critical component for sustainable management and policy definition; a complete understanding of the gonad development status of fish species is considered to be an important step for resource managers and fish culturists (Kohinoor, Islam, Mia, Rahman, \& Hussain, 2003). An effective management strategy recognizes that species not only depend on the existence of a suitable habitat, but also 
on its availability in the right time and place (Naiman \& Latterell, 2005), more especially for endemic species.

In view of its ecological and economic importance, the aim of the present study was to analyze the gonadal morphological development on P. shalynius, and define the successive maturation phase so that a clear understanding on its reproductive cycle can be gained including GSI, fecundity and ova-diameter. The data obtained can be utilized for future aquaculture planning and formulating conservation measures of this potential species which is regarded to be threatened, and whose natural habitats are being damaged and the population is rapidly declining due to anthropogenic activities in Meghalaya, India.

\section{MATERIALS AND METHODS}

Sample collection: $P$. shalynius were monthly collected with the help of local fishers, during daytime from the Umiam River, NorthEast India, between January 2010 to December 2011. The study area is situated at an altitude of $1020 \mathrm{msl}$ and falls at an intersection of $25^{\circ} 40^{\prime}$ $\mathrm{N}-91^{\circ} 54^{\prime} 20^{\prime \prime}$ E. Collection of live fishes started in January 18, 2010 and continued to collect every month. Fish were collected using cage net and other locally made traps like landing net. The samples were transported alive to the Fish Laboratory at the Department of Zoology, North Eastern Hill University, Shillong, and kept in the aquarium until fish were analyzed for the experiment.

Macroscopic study: Total length (TL) of each individual was measured to the nearest $0.1 \mathrm{~cm}$ and the total body weight (BW) was recorded to the nearest $0.1 \mathrm{~g}$ before dissecting each fish. The gonads were carefully removed and all surrounding tissues removed for further investigation. The gonad weight (GW) of each specimen was also weighed (accuracy of 0.01 $\mathrm{g}$ ), while the sex was determined by naked eye examination of the gonads. Fish length was measured with the help of a Vernier caliper (Mitutoyo Series 560) and weight was recorded using an Electronic Balance (A\&D EJ 200 Digital Scale).

Sex ratio: A total of 609 individuals were examined for sex ratio determination. The ovaries and testes of each fish were examined by naked eye as the gonads can be easily distinguished, belonging to a range of different developmental phases proposed by Grier, Uribe and Patino (2009). Deviation from the expected 1:1 sex ratio was analyzed using Chi-square test $\left(\chi^{2}\right)$ (Corder \& Foreman, 2009). For the entire statistical procedures, the level of significance was maintained at 0.05 .

Gonadosomatic index: The GSI was calculated following De Vlaming, Grossman and Chapman (1982):

$$
\mathrm{GSI}=(\mathrm{GW} / \mathrm{BW}) \times 100
$$

where, $\mathrm{GW}=$ Gonad weight, $\mathrm{BW}=$ Total body weight.

Fecundity: Fecundity was estimated from gravid females collected from the Umiam River throughout the study period, and was determined using the gravimetric method (Babiker \& Ibrahim, 1979). The ovary from the ripe females was removed from the fish and weighed. Two sub-samples of each, right and left ovary lobes, were kept in Gilson's fluid and shaken periodically to loosen the oocytes. Those that remained attached were teased off from the tissues during counting. Since dependence on GSI alone is not enough to determine gonadal maturation, oocyte diameters were also measured. Oocytes were counted and measured under a binocular microscope (Olympus CX31) using a calibrated phase micrometer. The absolute fecundity (AF) was calculated as suggested by Grimes and Huntsmen (1980). It was obtained by using the following formula:

$$
\mathrm{AF}=\mathrm{W} \times\left(\mathrm{N}_{1}+\mathrm{N}_{2}\right) /\left(\mathrm{w}_{1}-\mathrm{w}_{2}\right)
$$

where, $\mathrm{N}_{1}$ and $\mathrm{N}_{2}=$ number of eggs for each subsample, $\mathrm{W}=$ total weight of ovary and $\mathrm{w}_{1}$ and $\mathrm{w}_{2}=$ weight of the ovary for each sub-sample. 
Additionally to the absolute fecundity, relative fecundity (RF) has also been calculated following Hardisty (1964):

$$
\mathrm{RF}=\mathrm{AF} / \mathrm{BW}
$$

where, $\mathrm{AF}=$ Absolute fecundity, $\mathrm{BW}=$ Total body weight.

The regressions between fecundity and total length and body weight were calculated according to Bagenal (1978).

Meteriological information (rainfall and temperature): The data of annual rainfall and temperature of the study area and period was measured and provided by the Agricultural Engineering Division (ICAR, Umiam), Meghalaya. These were used to be compared with the GSI values, and to observe the influence of rainfall in fish spawning behavior.

\section{RESULTS}

Monthly variation in sex ratio showed that out of 609 fish analyzed, 283 (46.5\%) were males and 326 (53.5\%) were females (Table 1). The sex ratio in the different months observed was slightly different from the expected ratio of 1:1 (male: female). The overall sex ratio was 1: 1.16. Monthly fluctuation of sex ratio ranged from 1:0.75 (September) to 1: 2.17 (July), and was found to be statistically significant $(\mathrm{P} \leq 0.05)$ and skewed in favor of females. The following gonadal maturation phase were established for males and females based on macroscopic study: I = Rest, II = Primary growth, III = Secondary growth, IV = Ripe, $\mathrm{V}$ $=$ Spent (Table 2).

According to the monthly percentage composition of ovarian maturity phase (Fig. 1), females at phase I was observed in November and December, when the temperature decreased. The females at phase II were found in January and February as soon as the temperature starts rising. During March to May, as the temperature and rainfall increased, the gonad developed to the most advanced phase III. Phase IV specimens were recorded in June and July, that showed the peak of temperature and rainfall. The last phase $\mathrm{V}$ began to appear in the month of August onwards till October declaring completion of mature gonadal development, with the decline in temperature and rainfall. The testicular development of $P$. shalynius was similar to that of the ovary during the study period, having synchronicity. From December to February, most of the males were at phase I, followed by more advanced

TABLE 1

Monthly variation in sex ratio and chi-square test of Puntius shalynius in the Umiam river, Meghalaya, India

\begin{tabular}{cccccc} 
Month & Total sample & Male & Female & Sex ratio (M:F) & Chi-square test $\left(\chi^{2}\right)$ \\
Jan & 40 & 20 & 20 & $1: 1$ & 0 \\
Feb & 45 & 22 & 23 & $1: 1.05$ & 0.04 \\
Mar & 44 & 20 & 24 & $1: 1.2$ & 0.79 \\
Apr & 51 & 23 & 28 & $1: 1.22$ & 1.80 \\
May & 47 & 23 & 24 & $1: 1.04$ & 0.12 \\
Jun & 86 & 33 & 53 & $1: 1.61$ & 2.74 \\
Jul & 73 & 23 & 50 & $1: 2.17$ & $10.89^{*}$ \\
Aug & 43 & 23 & 20 & $1: 0.87$ & 2.80 \\
Sep & 49 & 28 & 21 & $1: 0.75$ & 4.54 \\
Oct & 42 & 20 & 22 & $1: 1.1$ & 1.91 \\
Nov & 41 & 21 & 21 & $1: 1$ & 0 \\
Dec & 48 & 27 & 21 & $1: 0.78$ & 3.81 \\
Total & 609 & 283 & 327 & $1: 1.16$ & $58.98^{*}$ \\
\hline
\end{tabular}

$\mathrm{M}=$ Male, $\mathrm{F}=$ Female; * Significant at $\mathrm{P} \leq 0.05$. 
TABLE 2

Macroscopic descriptions of gonadal maturation phase of Puntius shalynius in the Umiam river, Meghalaya, India

\begin{tabular}{|c|c|c|c|}
\hline \multirow{2}{*}{ Phase } & & \multicolumn{2}{|c|}{ Macroscopic appearance } \\
\hline & & Ovaries & Testes \\
\hline I & Rest & $\begin{array}{l}\text { Ovaries were small, thin, transparent and } \\
\text { whitish in colour. Oocytes not visible with } \\
\text { naked eyes }\end{array}$ & $\begin{array}{l}\text { The testes are small, thin, translucent and } \\
\text { ribbon- like }\end{array}$ \\
\hline II & Primary growth & $\begin{array}{l}\text { Ovaries become slightly larger, increase in } \\
\text { weight and volume and whitish in colour. } \\
\text { Oocytes are just visible through the ovary wall }\end{array}$ & $\begin{array}{l}\text { Testes become enlarge, increase in weight } \\
\text { and volume. Whitish in colour }\end{array}$ \\
\hline III & Secondary growth & $\begin{array}{l}\text { Very large occupying most of the abdominal } \\
\text { cavity, yellowish-orange and oocytes visible } \\
\text { without any aid }\end{array}$ & Large and milky white in colour \\
\hline IV & Ripe & $\begin{array}{l}\text { Occupying the entire abdominal cavity. Clear } \\
\text { orange in colour. Oocytes extruded on slight } \\
\text { pressure to abdomen }\end{array}$ & $\begin{array}{l}\text { Fully developed, milky-whitish in colour. } \\
\text { Milt run out of the fish }\end{array}$ \\
\hline $\mathrm{V}$ & Spent & Ovary flaccid, shrunk and without any oocytes & $\begin{array}{l}\text { The Testes become flaccid, thin and dull } \\
\text { white in colour }\end{array}$ \\
\hline
\end{tabular}

phase II in March and April. Testes at phase III appeared in May and from June onwards, they reached phase IV till early August. Testes were observed at phase $\mathrm{V}$ by the end of August and thereafter. In both cases, the peak spawning activity was principally observed in June and July.

Monthly variations in the mean GSI of males and females $P$. shalynius are presented in figure 2. In females, there was an overall increase in mean GSI from $4.71 \pm 0.39$ in February to a maximum value of $12.03 \pm 0.47$ in June, representing the peak of the spawning season. Subsequently, there was a decrease from August onwards with mean GSI value remained $6.38 \pm 1.19$. Mean GSI for males gradually increased from $0.99 \pm 0.07$ in January to $5.92 \pm 1.54$ in April and then declined to $1.65 \pm 0.16$ in May, and more dramatically to $0.87 \pm 0.12$ in October. The peak spawning season was observed once a year in June for females, and April for males. In the present study, males spawned earlier than females but breeding season extends until October for both sexes. It is worth mentioning that in many fishes, the peak reproductive activity did not coincide in males and females. The high value of GSI in females and males coincided with the high rainfall and temperature seasons (Fig. 2).
Gravid females were found in June and declined at the end of July. The sample ranged from 4.00 to $6.60 \mathrm{~cm}$ in total length and 0.65 to $3.97 \mathrm{~g}$ in body weight. The gonad weight of the specimens varied from 0.047 to $0.639 \mathrm{~g}$. The absolute and relative fecundity ranged from 47 to 1240 eggs, and 42 to 633 eggs per individual, respectively. The relationship between fecundity (F) and total length (TL) and total body weight (BW) may be described by the following equations:

$$
\begin{gathered}
\mathrm{F}=3.54 \times 10^{-1} \mathrm{TL}^{4.06}(\mathrm{r}=0.71) \\
\mathrm{F}=2.09 \times \mathrm{BW}^{1.31}(\mathrm{r}=0.72)
\end{gathered}
$$

The ova diameter progressively increased from $0.37 \mathrm{~mm}$ (March) to $0.90 \mathrm{~mm}$ (June) along with progression of maturity phase. Primary growth and mature ova were found in the ovaries during March - May (0.37-0.68 $\mathrm{mm}$ ) respectively. Ripe ova were found during June $(0.90 \mathrm{~mm})$ and July $(0.74 \mathrm{~mm})$ with the peak season in June (Fig. 3). The frequency of ripe ova fall down from August onwards till October and these were completely absent for four months during November to February when the fish is in resting phase, and indicated that the spawning season was over. Thereafter, their frequency began to rise from March. 

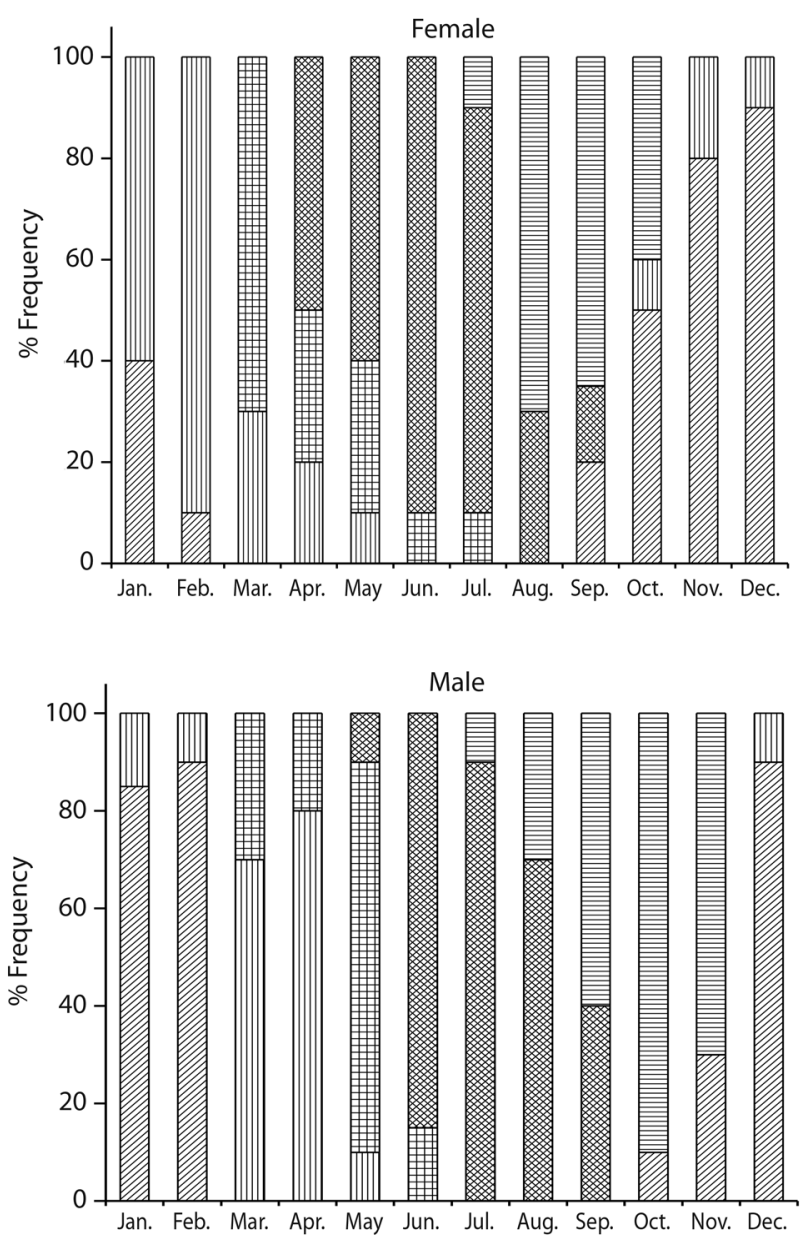

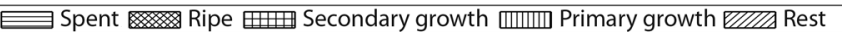

Fig. 1. Monthly changes in the frequency of occurrence of various maturation phases in Puntius shalynius of the Umiam river, Meghalaya, India.

No eggs were observed in the months of December and January.

In January, rainfall used to be less (1.6 $\mathrm{mm})$ with gradual increase in May $(429.9 \mathrm{~mm})$ and the maximum found in June $(880.6 \mathrm{~mm})$ then it decreases in July $(338.6 \mathrm{~mm})$ till it drops in December $(12.3 \mathrm{~mm})$. Temperature was observed low in December with $12{ }^{\circ} \mathrm{C}$ and high during July/August with $24{ }^{\circ} \mathrm{C}$ (Fig. 2).

\section{DISCUSSION}

The present study is the first with detailed information provided on the gonadal maturity in P. shalynius collected from its natural population, and described the annual maturation phase in both sexes. Reproductive cycle of a species provides information for its utilization in breeding programme of an endemic and threatened fish, especially $P$. shalynius. The results obtained from this study revealed that the species spawns once in a year from March to June in females, and March-April for males, and is a low fecund wild barb.

Sex ratio in different months showed some variations between males and females in the population. According to Nikolsky (1963) and Alp, Kara and Buyukcapar (2003), sex ratio 

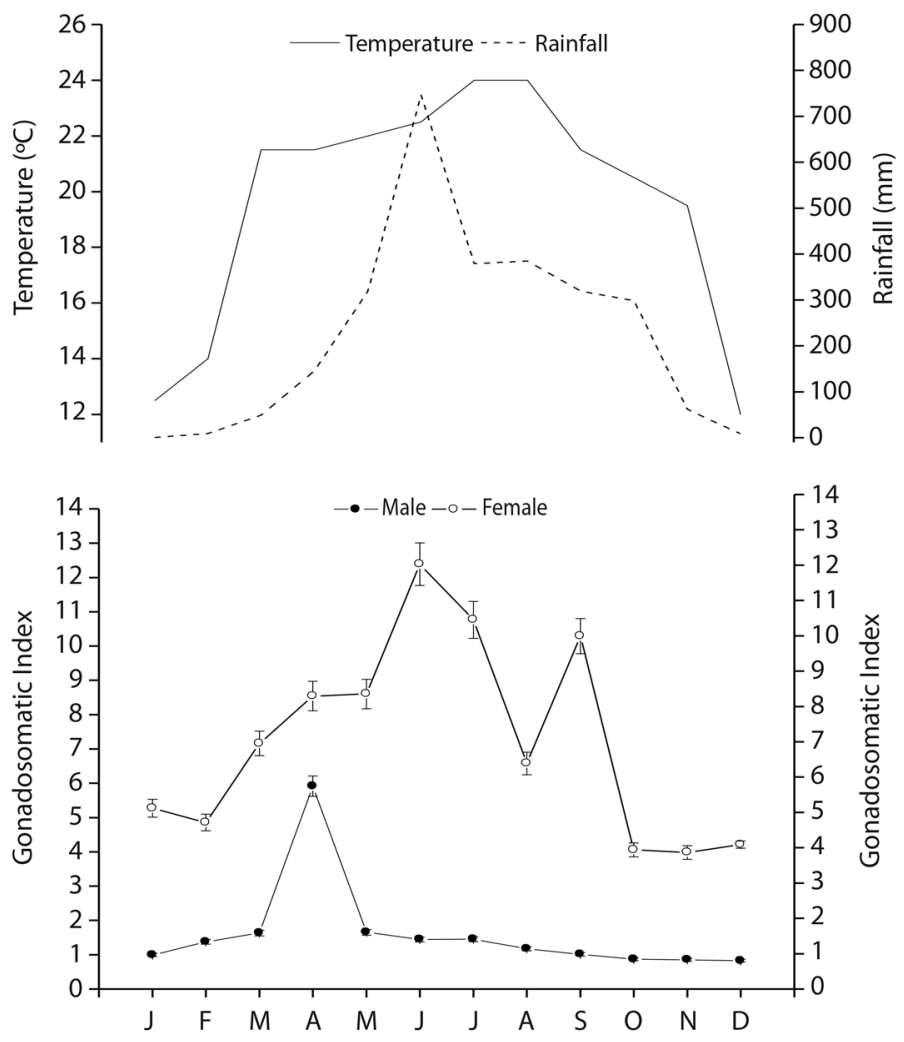

Fig. 2. Annual changes in temperature and rainfall of Barapani, Ribhoi District, India (upper panel), and monthly variation of gonadosomatic index (GSI; lower panel) in male and female of Puntius shalynius of the Umiam river, Meghalaya, India. Each point symbol on the line indicates mean \pm SEM of GSI.

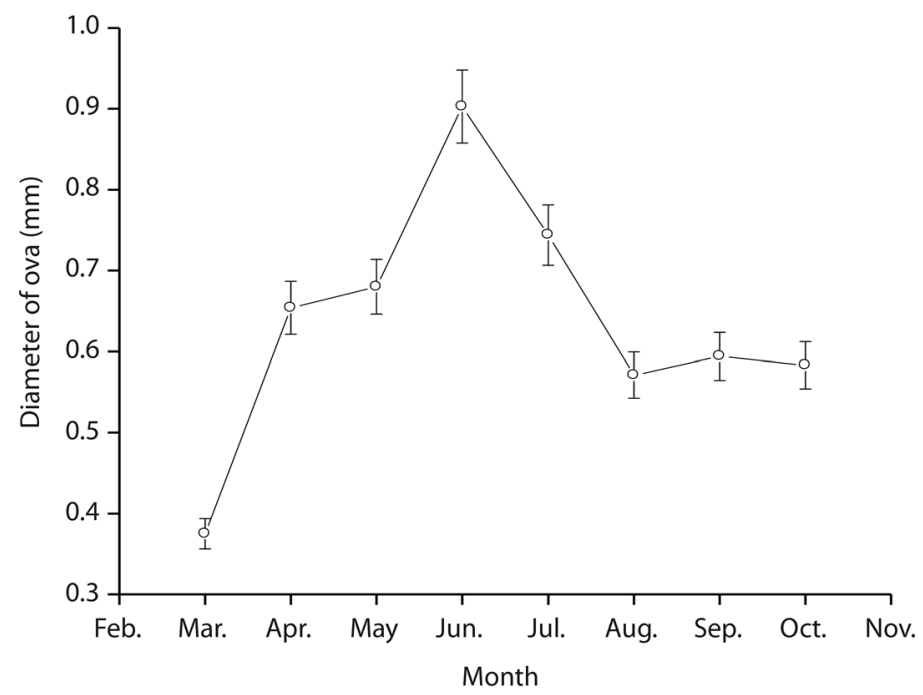

Fig. 3. Average ova diameter of Puntius shalynius during different months in the Umiam river, Meghalaya, India. 
of the fish may deviate from the normal 1:1 due to a number of factors. One possible reason for this skewed could be the differential habitat occupation of both sexes. Such differential habitat occupancy by sexes has been earlier observed in tropical fish (Lewis \& Fontoura 2005; Macuiane, Kaunda, Jamu, \& Kanyerere, 2009). Skewed ratios may also occur as a result of the differences in instantaneous natural mortality between sexes (Vincentini \& Araujo, 2003). Cek, Bromage, Randal and Rana (2001) observed significant deviation from normal sex ratio in $P$. conchonius $(1: 0.38)$ between females and males. The high number of females in reproductive season as observed in this study may favor the fish to produce high number of fertilized eggs thereby increasing the production of fry. There is gradual increase in the sex ratio (Male: Female) from March to July. The highest value of GSI in June for female indicated that the accumulation of large quantity of yolk in ripe ova reached at peak during this month. It can be conceived that this barb spends nearly six months investing in full development of ovary and another six months investing in reproduction in a year. Similar observation was made in other fishes such as $P$. dukai (Joshi \& Joshi, 1989) and Labeo rohita (Alam \& Pathak, 2010).

Gonad development and reproductive strategy have been described in many teleost fish species in an effort to understand the time course and reproductive cycle of the fish. In this investigation, five different maturity phases (I-V) of gonads have been described based on the macroscopic study. It is important to know the different phase of maturation to understand the time course and reproductive cycle of the fish. Similar phase of maturity have also been reported in Gobiodes rubicundus (Kader, Bhuiyan, \& Manzur-IKhuda, 1988), Mystus montanus (Arockiaraj, Haniffa, Seetharaman, \& Singh, 2004) and Astyanax fasciatus (Carvalho, de Paschoalini, Santos, Rizzo, \& Bazzoli, 2009).

Gonadosomatic index can be used to determine spawning season because GSI increases with the maturation of fish, being maximum during the period of the peak of maturity and declining abruptly thereafter, when the fish becomes spent (Stoumboudi, Villwock, Sela, \& Abraham, 1993). According to the present study, a GSI value of 12.03 was considered a reliable indicator of reproductive maturity for females. A high value of the GSI in June and its sharp decrease in the month of August showed that the fish have spawned during June/ July which is consistent with the result of that maturity stages. It can be concluded that the fish spawns once in a year with a single spawning peak. Mannan, Maridass and Thangarani (2010) observed that P. filamentosus spawns once as the maximum GSI value was found only in April.

Absolute fecundity of $P$. shalynius is extremely low when compared to other cyprinids such as Rasbora daniconius (Nagendran, Shakuntala, Natarajan, \& Vasan, 1981), whose fecundity ranged from 580 to 11040 eggs. In Barilius vagra, fecundity was observed with 800 to 3400 eggs (Gaur \& Pathani, 1996). Bhuiyan, Islam and Zaman (2006) obtained absolute fecundity of 2254 to 6964 eggs in P. gonionotus. Solomon et al. (2011) recorded absolute fecundity in $P$. denisonii from 376 to 1098 eggs, while relative fecundity was between 36 to 94 eggs similar with the present findings. The present observation on $P$. shalynius fecundity revealed that it is a low fecund fish when compared to other barbs. It is possible to suggest that the lower number of eggs can be correlated with short development time and low mortality rate of fingerlings, which means a higher survival rate of the fish. Thus, less number of eggs does not prove to be a disadvantage in reproductive potential.

The correlation coefficient (r) was found to be quite high (0.711 and 0.716) indicating a high degree of positive correlation between fecundity and total length, and fecundity and body weight. Similar findings were reported for P. ticto by Hossain, Rahman and Abdallah (2012) with the correlation coefficient value of 0.484 for fecundity and total length, whereas 0.63 for fecundity and body weight. Fecundity is directly proportional to size and body weight 
(Lehman, 1953). According to Jonsson and Jonsson (1999), fecundity increases with body size because the amount of energy available for egg production and the body cavity accommodating the eggs increase with fish size.

The ova diameter variation is one of the important evidences used in the determination of fish reproductive strategy (Tomasini, Collart, \& Quignard, 1996). The progressive change observed in the intra-ovarian diameter for a period not less than a year, can give an idea of the spawning periodicity of fish (Biswas, 1993). All the ova were found to be spherical and uniform in diameter indicating that the eggs were shed in a single batch. The ova diameter progressively increased from $0.375 \mathrm{~mm}$ (March) to $0.745 \mathrm{~mm}$ (July) along with progression of maturity phase. Ripe ova found in the month of July $(0.745 \mathrm{~mm})$ indicated that the fish spawn once in a year. In August, the mature eggs started to decline signaling the end of breeding season. There was no ova formation during November to February when the fish was in immature phase. Sundarabarathy, Edirisinghe and Dematawewa (2004) reported the ova diameter to be 0.628 to $0.681 \mathrm{~mm}$ in $P$. titteya. Abedi, Shiva, Mohammadi and Malekpour (2011) described that the ova diameter of Garra rufa ranged from 0.03 to $1.98 \mathrm{~mm}$, with a mean of $0.67 \mathrm{~mm}$. Saha (2011) observed that the ova diameter increased from 0.111 to 0.370 $\mathrm{mm}$ along with the progression of maturity phase in Salmophasia phulo.

It is important to understand the breeding pattern during the spawning season, in order to plan proper conservation strategies and to avoid fishing during the breeding season; this may consequently promote an increase in natural stocks. This specific characteristic is best done by monitoring the GSI and by observing the macroscopic features of gonad development. The gonads development both in females and males of $P$. shalynius was represented by five phases: (i) rest, (ii) primary growth, (iii) secondary growth, (iv) ripe and (v) spent. These phases were similar to the ones reported for $P$. sarana (Chakraborty, Mirza, Miah, Habib, \& Chakraborty, 2007).
The reproductive activity for both sexes of $P$. shalynius was influenced by environmental factors such as rainfall and water temperature for high value of GSI concurred with high rainfall and temperature. Again, rainfall acts as a cue for P. shalynius to breed, so that offspring are produced at times of better growth and survival. In freshwater teleosts, the high rainfall and temperature have been associated with spawning activity (Parkinson, Philippart, \& Baras, 1999). Many possible factors have been suggested by earlier researchers as influencing the spawning of freshwater fishes; some of these factors such as temperature, water flow, water level and precipitation, can serve as triggers for tropical fish reproduction (Wootton, 1995). In carps, it has been established that intensive flooding either caused by the rainfall or artificial means, capable of inundating shallow areas, are essential to induce spawning (Hora, 1945). Exogenous factors sometimes influence endogenous reproductive processes.

Studies on GSI and ova diameter suggests that the peak breeding season of $P$. shalynius is in June/July extending until October for both sexes with single spawning and the species is a low fecund fish. There is a need to develop successful management strategies so that fish stocks can be maintained for future generations. Fishes that do not meet adequate size limits are required to be released. To protect small fish of some species, minimum size limits can be set to allow juvenile fish to survive long enough to reproduce. Another measure is to initiate closed season for several threatened species for which harvest is prohibited, so as to protect fish during vulnerable time in its development or life history. The inference drawn from this study can be used as baseline information for planning effective conservation measures of this endangered and endemic species of North-East India.

\section{ACKNOWLEDGMENTS}

Authors are thankful to North Eastern Hill University, Shillong for financial support under UPE (University with Potential for Excellence) 
scheme of UGC to Life Sciences, Council of Scientific and Industrial Research (CSIR), Ministry of Environment and Forest (MoEF) and Head of Department of Zoology for giving permission to carry out the experiment and also for providing all the research facilities. Four anonymous referees and the administrative editor are thanked for helpful comments and constructive suggestions.

\section{RESUMEN}

Ciclo reproductivo del pez endémico y amenazado Puntius shalynius (Cypriniformes: Cyprinidae) en Meghalaya, India. Puntius shalynius es un pez de agua dulce altamente endémico que posee importancia económica y esta amenazado por su valor ornamental. En esta investigación se evaluó la maduración de las gónadas de este pez basado en la morfología y desove de esta especie en el río Umiam, Meghalaya, India. La población de esta especie nativa ha decrecido debido a su distribución fragmentada y explotación como pez ornamental. El ciclo reproductivo de P. shalynius se estudió por primera vez. En el río se recolectó al azar una muestra de 609 peces por un período de dos años entre enero 2010 y diciembre 2011. Se observaron cinco estadios de madurez (descanso, crecimiento primario, crecimiento secundario, maduro, agotamiento) basados en la evaluación macroscópica testicular y ovárica durante el ciclo anual. La actividad máxima del desove se observó entre junio y julio lo que coincidió con el comienzo de la época de monzones. El estudio demostró que estos peces desovan una vez al año con un único punto máximo y que la especie es de baja fecundidad. Es importante la conservación de esta especie por su valor ecológico único y se deben promover políticas de manejo urgentes para su uso sostenible.

Palabras clave: Puntius shalynius, endémico, ornamental, índice gonadosomático, India.

\section{REFERENCES}

Abedi, M., Shiva, A. H., Mohammadi, H., \& Malekpour, R. (2011). Reproductive biology and age determination of Garra rufa Heckel, 1843 (Actinopterygii: Cyprinidae) in central Iran. Turkish Journal of Zoology, $35,317-323$.

Alam, M., \& Pathak, J. A. (2010). Assessment of fecundity and gonadosomatic index of a commercially important fish Labeo rohita from Ramganga River. International Journal of Pharma Bio Sciences, 1(3), 1-6.

Alp, A., Kara, C., \& Buyukcapar, H. M. (2003). Reproductive biology of brown trout, Salmo trutta macrostigma
Dumeril 1858, in a tributary of the Ceyhan river which flows into the eastern Mediterranean sea. Journal of Applied Ichthyology, 19, 346-351.

Angermeier, P. L. (1995). Ecological attributes of extinction-prone species: loss of freshwater fishes of Virgina. Conservation Biology, 9, 143-158.

Arockiaraj, A. J., Haniffa, M. A., Seetharaman, S., \& Singh, S. (2004). Cyclic changes in gonadal maturation and histological observations of threatened freshwater catfish Mystus montanus (Jerdon, 1849). Acta Ichthyologica et Piscatoria, 34, 253-266.

Babiker, M. M., \& Ibrahim, H. (1979). Studies on the biology of reproduction in the ciclid, Tilapia nilotica $(\mathrm{L})$ : gonadal development and fecundity. Journal of Fish Biology, 14, 437-448.

Bagenal, T. B. (1978). Aspects of fish fecundity. In S. D. Gerking (Ed.), Ecology of freshwater fish production (pp. 75-101). Oxford, U.K.: Blackwell Scientific Publications.

Bhuiyan, A. S., Islam, K., \& Zaman, T. (2006). Fecundity and ovarian characteristics of Puntius gonionotus (Bloch/Bleeker) (Cyprinidae: Cypriniformes). Journal of Bio-Science, 14, 99-102.

Biswas, S. P. (1993). Manual of methods in fish biology. Delhi, South Asian: Publishers Pvt. Ltd.

Carvalho, P. A., de Paschoalini, A. L., Santos, G. B., Rizzo, E., \& Bazzoli, N. (2009). Reproductive biology of Astyanax fasciatus (Pisces: Characiformes) in a reservoir in Southeastern Brazil. Journal of Applied Ichthyology, 25, 306-313.

Cek, S., Bromage, N. R., Randal, C., \& Rana, K. (2001). Oogenesis, hepatosomatic and gonadosomatic indexes and sex ratio in Rosy barb (Puntius conchonius). Turkish Journal of Fisheries and Aquatic Science, 1, 33-41.

Chakraborty, B. K., Mirza, Z. A., Miah, M. I., Habib, M. A. B., \& Chakraborty, A. (2007). Reproductive cycle of the endangered sarpunti, Puntius sarana (Hamilton, 1822). Bangladesh Asian Fisheries Science, 20, 145-164.

Corder, G. W., \& Foreman, D. I. (2009). Nonparametric statistics for non-statisticians: A step-by-step approach. John Wiley and Sons, Inc.

De Vlaming, V., Grossman, G., \& Chapman, F. (1982). On the use of gonadosomatic index. Comparative Biochemistry and Physiology, 73, 31-39.

Gaur, S. K., \& Pathani, S. S. (1996). Fecundity of the lesser baril Barilius vagra (Hamilton) from Kumaun Nainital. Indian Journal of Fisheries, 43, 381-384.

Grier, J. H., Uribe, A. M. C., \& Patino, R. (2009). The ovary, folliculogenesis and oogenesis in teleosts. 
In B. G. M. Jamieson (Ed.), Reproductive Biology and Physiology of Fishes (Agnathans and Bony Fishes) (pp. 25-84). USA: Science Publishers.

Grimes, C. B., \& Huntsman, G. R. (1980). Reproductive biology of vermilion snapper, Rhomboplites aurorubens from North Carolina and South Carolina. Fishery Bulletin, 78, 137-146.

Hardisty, M. W. (1964). The fecundity of lampreys. Archive fur Hydrobiologie, 60, 340-357.

Hora, S. L. (1945). Analysis of factors influencing the spawning of carps. Symposium on the factors influencing the spawning of Indian carps. Proceedings of National Institute Science of India, 11, 303-312.

Hossain, M. Y., Rahman, M. M., \& Abdallah, E. M. (2012). Relationships between Body Size, Weight, Condition and Fecundity of the Threatened Fish Puntius ticto (Hamilton, 1822) in the Ganges River, Northwestern Bangladesh. Sains Malaysiana, 41, 803-814.

IUCN Red List of Threatened Species, Version 2010.04. (2015). Gland: International Union for the Conservation of Nature and Natural Resources. http://www. iucnredlist.org/apps/redlist/details/19488/0

Jayaram, K. C. (1999). The freshwater fishes of the Indian region. New Delhi, India: Narendra Publishing House.

Jonsson, N., \& Jonsson, B. (1999). Trade-off between egg mass and egg number in brown trout. Journal of Fish Biology, 55, 767-783.

Joshi, K. D., \& Joshi, P. C. (1989). Seasonal cycle of testicular maturation and interstitial cell activity in the hill-stream teleost, Puntius dukai (Day). Indian Journal of Fisheries, 36(1), 58-64.

Kader, M. A., Bhuiyan, A. L., \& Manzur-I-Khuda, A. R. M. M. (1988). The reproductive biology of Gobioides rubicundus (Hamilton-Buchanan) in the Karnaphuli estuary, Chittagong. Indian Journal of Fisheries, $35,239-250$

Kohinoor, A. H. M., Islam, M. S., Mia, M. Y., Rahman, M. A., \& Hussain, M. G. (2003). Evaluation of different stocks of Chinese carp in Bangladesh: Design and preliminary results (pp. 59-67). In Proceedings of a workshop on genetic management and improvement strategies for exotic carp in Asia, Dhaka, Bangladesh.

Lehman, B. A. (1953). Fecundity of Hudson river shad. U. S. Fish and Wildlife Service, Research Report 33.

Lewis, D. S., \& Fontoura, N. F. (2005). Maturity and growth of Paralonchurus brasiliensis females in southern Brazil (Teleostei, Perciformes, Sciaenidae) Journal of Applied Ichthyology, 21, 94-100.

Macuiane, M. A., Kaunda, E. K. W., Jamu, D. M., \& Kanyerere, G. Z. (2009). Reproductive biology and breeding of Barbus paludinosus and B. trimaculatus (Teleostei: Cyprinidae) in lake Chilwa, Malawi: implications for fisheries management. African Journal of Aquatic Science, 34, 123-130.

Mannan, M. M., Maridass, M., \& Thangarani, S. (2010). Gonad developmental cycle of Puntius filamentosus. International Journal of Biotechnology, 1, 69-77.

Manorama, M., \& Ramanujam, S. N. (2011). Lengthweight relationship of freshwater fish, Puntius shalynius Yazdani and Talukdar (Cypriniformes: Cyprinidae), in Meghalaya, India. Journal of Applied Ichthyology, 27, 1404-1405.

Manorama, M., \& Ramanujam, S. N. (2014). Condition factor and relative condition factor of an ornamental fish, Puntius shalynius Yazdani and Talukdar in Meghalaya, India. International Journal of Research in Fisheries and Aquaculture, 4, 77-81.

Nagendran, R., Shakuntala, K., Natarajan, G. N., \& Vasan, H. R. K. (1981). Observations on the fecundity of the cyprinid Rasbora deniconius (Hamilton). Proceedings of Indian Academy of Science, 90, 381-388.

Naiman, R. J., \& Latterell, J. J. (2005). Principles for linking fish habitat to fisheries management and conservation. Journal of Fish Biology, 67, 166-185.

Nikolsky, G. V. (1963). The Ecology of Fishes. London, New York: Academic Press, INC.

Parkinson, D., Philippart, J., \& Baras, E. (1999). A preliminary investigation of spawning migrations of grayling in a small stream as determined by radio-tracking. Journal of Fish Biology, 55, 172-182.

Saha, S. (2011). Ichthyofaunal diversity in two wetlands of Goalpara district, Assam with reference to ecobiology of certain fish species (Ph.D. Thesis). Gauhati University, India.

Solomon, S., Ramprasanth, M. R., Baby, F., Pereira, B., Tharian, J., Ali, A., \& Raghavan, R. (2011). Reproductive biology of Puntius denisonii, an endemic and threatened aquarium fish of the Western Ghats and its implications for conservation. Journal of Threatened Taxa, 3, 2071-2077.

Stoumboudi, M. T. H., Villwock, W., Sela, J., \& Abraham, M. (1993). Gonadosomatic index in Barbus longiceps, Capoeta damascina and their natural hybrid (Pisces, Cyprinidae), vs spermatozoan index in the parental males. Journal of Fish Biology, 43, 865-875.

Sundarabarathy, T. V., Edirisinghe, U., \& Dematawewa, C. M. B. (2004). Captive breeding and rearing of fry and juveniles of cherry barb (Puntius titteya Deraniyagala), a highly threatened endemic fish species in Sri Lanka. Tropical Agricultural Research, 16, 137-149.

Tomasini, J. A., Collart, D., \& Quignard, J. P. (1996). Female reproductive biology of the sand smelt 
in brackish lagoons of southern France. Journal of Fish Biology, 46, 594-612.

Vincentini, R. N., \& Araujo, F. G. (2003). Sex ratio and size structure of Micropogonias furnieri (Desmarest 1823) (Perciformes: Sciaenidae) in Sepetiba Bay, Rio De Janeiro, Brazil. Brazilian Journal of Biology, $63,559-566$.
Wootton, R. J. (1995). Ecology of teleost fishes. London, England: Chapman and Hall.

Yazdani, G. M., \& Talukdar, S. K. (1975). A new species of Puntius (Cypriniformes: Cyprinidae) from Khasi and Jaintia Hills (Meghalaya), India. Journal of Bombay Natural History Society, 72, 218-221. 
